\title{
A MONOGRAPH OF THE VOCHYSIACEAE
}

\author{
IV. ERISMA ${ }^{1}$ \\ BY \\ F. A. STAFLEU (Utrecht)
}

(Received Sept. 11th, 1954)

The genus Erisma is found in the Amazonian basin and in the Guianas; it comprises 16 species as defined in this paper, all of them typical Hylaean forest trees.

The genus was first described by RUDGe in 1805; its name is a greek word meaning "a cause of dispute". RUDGE may have wanted it to refer to the romantic story of the type-specimen of his Erisma floribundum, a specimen belonging to a set of plants collected by the Frenchman Martin in French Guiana and captured by British privateers on its way to Paris. The name was also well suited to indicate the difficult taxonomic position of the genus.

\section{AcknowledGments}

This conclusion of a revision of the Vochysiaceae has been made possible by the courtesy and collaboration of a great number of herbaria and institutions listed in the second part of this Monograph. The author expresses once again his deep gratitude to the directors of these institutions for the generous way in which they placed their collections at his disposal.

The revisional work has been accomplished at the Utrecht Botanical Museum and the author is greatly indebted to the director, $\mathrm{Dr} \mathrm{J}$. Lanjouw, whose stimulating interest and great help have always been of great value to him. The author is also greatly obliged to $\mathrm{Mr}$ N. Y. Sandwith of Kew for his constant help and assistance.

\section{Morphological Remarks}

The South-american genus Erisma and the Central-african Erismadelphus constitute the tribe Erismeae Dumort. of the Vochysiaceae. The comparative morphology of the tribe Vochysieae and that of the family as a whole was discussed in some detail in the second part of this Monograph. The following remarks are mainly concerned with the variation inside the Erismeae and its genera.

The diagram of the flower of an Erisma species is given in Fig. 4, a diagram of the flower of Erismadelphus sessilis is given by KEAY and Stafleu (1952, p. 596).

1 Parts I-III are listed under "References". 
The calyx is very characteristic: the cup envelopes the indehiscent fruit and is crowned by the wing-shaped enlarged calyx-lobes. The spurred (fourth) lobe is deciduous in Erisma but persistent in Erismadelphus, the fruit of the former genus is therefore four-winged, that of the latter five-winged. The calyx is of the Salvertia-type (cf. Stafleu 1953, p. 145): the spurred lobe is only slightly larger than the other lobes and the latter are never closely adpressed against the former.

The corolla of Erismadelphus consists of a complete set of five petals linking up with the quincuncial aestivation of the calyx, that of Erisma is reduced to a single petal corresponding with the third petal of Erismadelphus and Salvertia. Rudimentary petals are rarely present.

The only fertile stamen of Erisma (and Qualea) stands in front of the fifth calyx-lobe, outside the plane of symmetry; that of Erismadelphus (and Vochysia), on the other hand, stands in the symmetry plane at the base of the (third) petal. They obviously belong to different cycles: to an outer cycle in Erisma, to an inner cycle in Erismadelphus. The staminodes always belong to the inner cycle.

It follows that-morphologically speaking-the flowers of the African genus Erismadelphus are much simpler than those of the American Erisma: the corolla is complete and the flower is perfectly symmetrical.

The ovary of the Erismeae is inferior or nearly so and unilocular, that of the Vochysieae is superior and trilocular.

The fruits resemble the fruits of the Asian Dipterocarpaceae on account of the wing-shaped enlarged calyx-lobes. 'They contain a single wingless seed, are indehiscent and enclosed by the thickened persistent calyx-cup. The Vochysieae have dehiscent trilocular capsules with winged seeds.

The common feature of the inflorescence of all Vochysiaceae is the cincinnus. In the Erismeae these cincinni are arranged in ample panicles. The characters of the bracts provide the main criterion of division, between the two sections of Erisma. The outer bracts are always much larger than the inner ones and in the section Erisma they even surpass in length the flower-bud together with the distal part of the cincinnus. Young cincinni in which the first flower is still a bud are thus completely covered by the outer bract of this flower, it drops during or shortly after anthesis and then the outer bract of the next flower covers the remaining part of the cincinnus, and so on. In the section Rixa the outer bracts are smaller and drop earlier, the inner bracts are often absent.

\section{Geobotanical and Ecological Remarks}

A peculiarity of the tribe Erismeae is of course its bicontinental distribution (see fig. 1). The two species of Erismadelphus are the only representatives of the Vochysiaceae, out of a total of about 190 species, outside the New World. No species are known from Atlantic or Caribbean islands.

The area of Erisma is strictly limited to the Amazonian basin and 
the Guianas. All species but one are characteristic trees of the Hylaean terra firme rain-forest; Erisma calcaratum, however, is a varzea tree and it is interesting to note that its fruits are well adapted to water

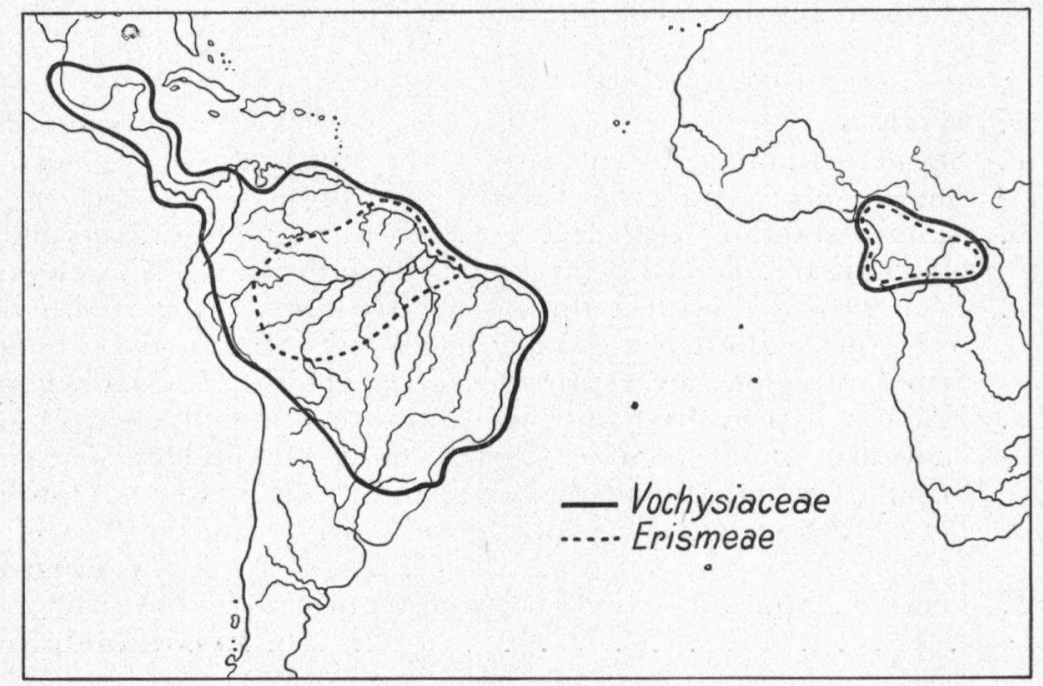

Fig. 1. Distribution of the Vochysiaceae and its tribe Erismeae

transport. Unlike those of the other species, the wings of its fruits are poorly developed but the calyx-cup is exceptionally thick and woody.

\section{Notes AND Abbreviations}

Most of the species of Erisma are of very little economic value. The wood seems to be poor but in one or two species an oil is extracted from the seeds ( $E$. calcaratum, $E$. japura).

The abbreviations that have been used for the herbaria are those of the Index Herbariorum (Lanjouw and Stafleu 1954).

\section{Erismeae Dumort.}

Dumortier, Analyse des familles des plantes 6. 1829 ("Erismaceae"); Baillon 1874 p. 96, 100, 103; Chevalier \& Russel 1929 p. 565; Stafleu 1952 p. 223; Keay \& Stafleu 1952 p. 594.

Trees. Hairs generally stellate. Calyx semisuperior. Ovary unilocular, inferior or semi-inferior. Fruit indehiscent, enclosed by the enlarged calyx-cup and winged on account of the enlarged calyxlobes. Seeds wingless, one per fruit.

Type genus: Erisma Rudge.

Distribution: Two genera, one in Amazonian South-america and one in West tropical Africa (cf. Fig. 1). 


\section{Key to the genera of the Vochysiaceae}

1. a. Ovary superior, trilocular. Fruit dehiscent . . . . . . . . tribus I Vochysieae 2

b. Ovary inferior or semi-inferior, unilocular. Fruit indehiscent, enclosed by the calyx-cup and the enlarged calyxlobes . : .

2. a. Petals 3 i or 0.0 tribus II Erismeae 5

b. Petals 5 , $0 . \ldots \ldots$

3. a. Stamen standing at the base of the fifth calyx-lobe, outside the plane of symmetry. Petal 1 , convolute . . . . . . 4

$b$. Stamen standing at the base of the central petal, in the plane of symmetry. Petals 3 , rarely 1 or 0 , imbricate. 2. Vochysia

4. a. Fruit provided with a thick central column, exocarp fragile, only the endocarp regularly trivalved. Staminodes absent. Stipular region never provided with glands. 3. Callisthene

$b$. Fruit not provided with a central column. Exocarp and endocarp both regularly trivalvous. Staminodes present. Stipular region provided with glands . . . 4. Qualea

5. a. Petal 1. Spurred calyx-lobe deciduous. (Tropical America)

b. Petals 5. Spurred calyx-lobe persistent (Tropical Africa).

\section{Erisma Rudge}

Rudge, Pl. Gui. 1: 7. 1805; Martius 1824 p. 136; E. Meyer 1825 p. 812 ; D.C. 1828 p. 29 ; A. Dietrich 1831 p. 101 ; Poeppig 1833 p. 121; Meisner 1836-43 p. 119; Endlicher 1840 p. 1179 ; Benth. \& Hook. 1867 p. 967 ; Baillon 1874 p. 103; Warming 1875 p. 106; Petersen 1896 p. 319 ; Benoist 1915 p. 236; - 1931 p. 169; Ducke 1938 p. 38; Mennega 1948 p. 47 (wood anatomy, references); Macbride 1950 p. 872; Stafleu 1951 p. 196; Lemée 1952 p. 243. Debraea Roem. \& Schult. 1817 p. $34,-1822$ p. 50. Ditmaria Spreng. 1818 p. $704,-1825$ p. $16,-1827$ p. 8. Braya Schult. ex Mart. 1824 p. 136 in synon.

Trees. Indumentum (except where otherwise stated) consisting of stellate hairs. Perulate buds rarely present. Stipules absent or small. Leaves opposite or in whorls, simple, petioled, entire, coriaceous or subcoriaceous, penninerved, the petioles mostly canaliculate above, the midrib prominent below. Flowers hermaphrodite, irregular; cincinni 2-5 flowered, peduncled, arranged in ample panicles, accessory axes often present in the inflorescence. Pedicels bibracteate, the outer bracts larger than the inner ones. Calyx semisuperior, gamosepalous, quincuncial, densely stellate-pilose, the base cupshaped, the limb five-parted, the lobes unequal, the fourth ("posterior", "major") lobe deciduous, spurred, irregularly suborbicular or subobcordate, two-winged, convolute, the inner wing petaloid, its inner side provided with a tuft of (mostly c. $1 \mathrm{~mm}$ ) long simple hairs, the other lobes smaller, persistent and in nearly all species excrescent 
and enveloping the fruit, the second and third ones larger than the first and fifth ones, the fifth one always subtriangular and more or less acute. Corolla, stamen and staminodes epigynously inserted on the calyx. Petal one, violaceous, yellow or white, membranous, convolute, alternating with the third and fifth calyx-lobes, caducous, generally obcordate, the apex two-lobed, the base unguiculate. Rudimentary petals rarely present. Stamen one, in front of the fifth calyx-lobe, deciduous, glabrous, the filament laterally flattened, the anther bithecate, about half as long as the filament, the base subhastate or emarginate, the filament attached above the base, the pollen grains triporous ("tricolpate"). Staminodes 0-4, petaloid, small, alternating with the calyx-lobes, rarely one in front of the second calyx-lobe and belonging to the cycle of the fertile stamen. Ovary nearly inferior, the free apical part pilose, unilocular. Ovules 2, epitropic, inserted on the same side as the petal, integuments 2 . Style simple, not elongated after anthesis. Stigma one, capitate. Fruit indehiscent, coriaceous, ellipsoid, the base of the style persistent, remaining in the calyx-cup and crowned by the enlarged wing-shaped smaller calyx-lobes, the major wing (the third calyx-lobe) at least twice as long as the other ones, the second lobe constituting the second wing, the first and fifth lobes constituting the two smallest wings, the fifth generally subtriangular and more or less acute. Wings very small in one species but then calyx-cup strongly developed. Seeds one per fruit, oblong, not winged. Embryo homotropous, straight, radicle small, cotyledons flat.

Typification: Type species of Erisma Rudge (1805), Debraea Roem. \& Schult. (1817) and Ditmaria Spreng. (1818, 1825): Erisma floribundum Rudge. The generic name Braya was not validly published, being given in synonomy.

\section{Distribution: Sixteen species in the Amazonian basin and Guiana.}

Ecology: Nearly all the species are found in primeval forests on terra firme.

Remarks on the subdivision: The subdivision by Warming (1875) still holds: "Sect. I Warm." being Sect. Erisma, „Sect. II Warm." being named Rixa; the latter name is almost a linguistic synonym of the former.

\section{Key to the species}

1. a. Outer bracts dropping late, larger than the subtended flowers, enveloping the young cincinni. Inner bracts always present . . . . . . . . Section I Erisma 2

$b$. Outer bracts deciduous, smaller than the subtended flowers, never enveloping these flowers and the distal part of the cincinnus. Inner bracts small and deciduous or absent . .

2. a. Adult leaves pilose below . . . . Section II Rixa 1

b. Adult leaves glabrous or with a few scattered hairs . 8

3. a. Petioles about $\frac{1}{2}-1 \frac{1}{2} \mathrm{~cm}$ long; blades $3-6 \mathrm{~cm}$ wide. . 4

$b$. Petioles about $2 \frac{1}{2} \mathrm{~cm}$ long; blades $15-25 \times 5-12 \mathrm{~cm}$. . la. E. bicolor Ducke var. bicolor

4. a. Lateral nerves strongly (,costate") prominent below, leaves coriaceous . . . . . . . . . . . . . 5

b. Lateral nerves not or only slightly prominent below, leaves 
rigid . . . . . . . 2. E. laurifolium Warm.

G. a. Inner bracts linear-subulate, 1-2 $\mathrm{mm}$ long; petioles $10-17 \mathrm{~mm}$ long . . . . . . . . . . . . . . 6

b. Inner bracts oblanceolate-spathulate, 3-4 $\mathrm{mm}$ long; petioles 4-9 mm long . . . . . . . . . . . . . . . . . . 7

6. a. Petioles $3-3 \frac{1}{2} \mathrm{~mm}$ wide; leaves $4 \frac{1}{2}-7 \mathrm{~cm}$ wide .

$3 a$. E. costatum Stafl. var. costatum

b. Petioles $1 \frac{1}{2}-2 \mathrm{~mm}$ wide; leaves $3 \frac{1}{2}-4 \frac{1}{2} \mathrm{~cm}$ wide

- . $3 b$. E costatum Stafl. var, gracilipes Stafl.

7. a. Petal glabrous .

b. Base of the petal lanuginose inside.

4b. E. floribundum Rudge var. tomentosum (Ducke) Stafl.

8. a. Petioles c. $\frac{1}{2}-1 \frac{1}{2} \mathrm{~cm}$ long; stipules present . . . . . . 9

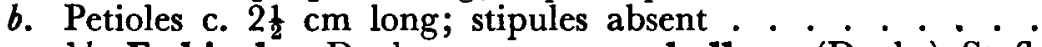

1b. E. bicolor Ducke var. macrophyllum (Ducke) Stafl.

9. a. Leaves $6-11 \times 2 \frac{1}{2}-4 \frac{1}{\mathrm{~cm}}$; flower-buds $4-5 \mathrm{~mm}$ long . 10

b. Leaves $12-22 \times 6-11 \mathrm{~cm}$; flower-buds c. $10 \mathrm{~mm}$ long ..

10. a. Spur subglobose, bag-shaped, c. $1 \frac{1}{2} \times 1 \frac{1}{2} \mathrm{~mm}$; outer bracts c. $4 \mathrm{~mm}$ long . . . . . . . . 6. E. gracile Ducke

b. Spur straight, slender, c. $4 \mathrm{~mm}$ long; outer bracts c. $7 \mathrm{~mm}$ long . . . . . . . 7. E. tessmannii Pilger

11. a. Indumentum of the inflorescence brownish . . . . . 12

$b$. Indumentum of the inflorescence greyish or yellowishgreyish . . . . . . . . . . . 16

12. a. Leaves elliptic or obovate, about twice as long as wide 13

$b$. Leaves lanceolate, about three times longer than wide. .

13. a. Petioles $3-10 \mathrm{~mm}$ long

$b$. Petioles c. $10 \mathrm{~mm}$ long; lateral nerves making an angle of c. $50^{\prime}$ with the midrib . . 9. E. megalophyllum Stafl.

14. a. Spur straight, leaves glabrous below . . . . . . . 15

b. Spur uncinate-incurved; leaves pilose below 15. a. Petioles 3-5 mm long; spur c. $1 \frac{1}{2} \mathrm{~mm}$ long . . . . . . b. . 11. E. micranthum Spruce ex Warm. b. Petioles 8-10 mm long; spur 4-5 mm long .

16. a. Leaves opposite, or if verticillate spur uncinate-incurved 17

b. Leaves verticillate; spur bag-shaped

17. a. Petioles $3-6 \mathrm{~mm}$ long

b. Petioles 10-20 mm long. . . . . . . . . . . . . . 19

18. a. Flower-buds up to $5 \mathrm{~mm}$ long; fruits winged . . . . . . . . . . . 11. E. micranthum Spruce ex Warm.

b. Flower-buds up to $10 \mathrm{~mm}$ long; fruits not winged . . .

19. a. Spur uncinate-incurved; leaves pilose below . 
15. E. uncinatum Warm.

b. Spur straight or slightly incurved; leaves glabrous . . . . . 16. E. splendens Stafl.

\section{section I Erisma}

Sect. I Warming, Fl. Bras. 13(2): 108. 1875.

Bracteae persistentes vel semipersistentes, ultimae maximae axes cum floribus et bracteis insequentes ante evolutionem tegentes.

Holotypus: Erisma foribundum Rudge.

1. Erisma bicolor Ducke, Bull. Mus. Hist. Nat. Paris II. 4: 740. 29 Nov. 1932 ; - 1933 p. $47,-1935$ p. 56, - 1938 p. 44. Erisma petiolatum Gleason, 1933 p. 363.

\section{a. var. bicolor}

Large tree. Young branchlets, petioles, buds, leaves below, inflorescence, bracts and calyx densely brownish pilose. Stipules absent. Leaves opposite; petioles firm, c. $2 \frac{1}{2} \mathrm{~cm}$ long; leaf-blades obovate or elliptic-obovate, $15-25 \times 5-12 \mathrm{~cm}$, the apex acuminate, the base more or less obtuse or acute; lateral nerves strongly prominent below, $15-18$ on each side, angle with the midrib $50-60^{\prime}$, marginal nerve undulate, at $1-2 \frac{1}{2} \mathrm{~mm}$ from the margin. Panicles up to $30 \times 30 \mathrm{~cm}$, many-flowered, the cincinni 2-5 flowered, up to $2 \frac{1}{2} \mathrm{~cm}$ long, the peduncles up to $10 \mathrm{~mm}$ long, the pedicels $1-3 \frac{1}{2} \mathrm{~mm}$ long, the outer bracts ovate, obtuse, up to $9 \times 6 \mathrm{~mm}$, the inner bracts subulate, c. $1 \mathrm{~mm}$ long, the flower-buds $6-8 \mathrm{~mm}$ long. Flowers fragrant. Fourth calyx-lobe violaceous, about $8 \mathrm{~mm}$ long and 10-12 $\mathrm{mm}$ wide, the spur ascending, recurved, cylindrical, c. $3 \mathrm{~mm}$ long. Petal white, up to $15 \times 18 \mathrm{~mm}$. Style c. $8 \mathrm{~mm}$ long, basal half pilose, upper half violaceous. Fruit winged, the major wing oblong, $6-8 \times 2-3 \mathrm{~cm}$, rounded, the second wing elliptic, c. $3 \mathrm{~cm}$ long, rounded.

Holotype: Ducke RB 23500 in RB from Borba (Brazil, Amazonas), duplicates in: G, K, NY, P, S, U, US. Holotype of E. petiolatum Gleason: Krukoff 1334 in NY, duplicates: A, F, G, MO, P, S, U.

Distribution: C. Amazonas and N. Matto Grosso.

BRAZIL, Amazonas: Near Borba, Rio Madeira inf., Ducke 23500; Manáos, Ducke RB 23796. Matto Grosso: Near Tabajara, upper Machado River region, Krukoff 1334 and 1376 .

Ecology: On terra firme along fringes of marshes; fl. Nov.-Jan., fr. May (1 report).

b. var. macrophyllum (Ducke) Stafl. nov. comb. Erisma macrophyllum Ducke 1938 p. 44.

Small tree. Branchlets and lower surface of the leaves glabrous or nearly so and therefore leaves not "bicolor". Indumentum of the inflorescence less dense than in var. bicolor. Major wing of the fruit subelliptic.

Holotype: Ducke RB 34.685 in RB, along Rio Curicuriary (Brazil, Amazonas), duplicates in: K, US.

Distribution: Upper Amazonia.

BRAZIL, Amazonas: Rio Curicuriary, Ducke RB 34685; São Paulo de Olivença, Krukoff 8892.

Ecology: On terra firme, fr. Febr. (one report). 
2. Erisma laurifolium Warm. Fl. Bras. 13(2): 109. t. 20. 1875; Petersen 1896 fig. 173 A-F; Ducke 1938 p. 42 . Qualea laurifolia Spruce ex Warm. l.c. in synon.

Large tree. Branchlets, petioles, buds, leaves below, inflorescence, bracts and calyx densely pilose. Buds pedicelled. Stipules absent. Leaves opposite; petioles c. $1-1 \frac{1}{2} \mathrm{~cm}$ long, articulate at the base; leaf-blades oblong or elliptic-oblong, $11-13 \times 4-5 \frac{1}{2} \mathrm{~cm}$, often folded, the apex abruptly long-acuminate, rarely obtuse, the base obtuse; lateral nerves slightly prominent below, $10-15$ on each side, angle with the midrib $60-80^{\prime}$, anastomosing near the margin, marginal nerve absent. Panicles provided with $2-4(-7)$ flowered cincinni, the peduncles up to $10 \mathrm{~mm}$, the pedicels up to $3 \mathrm{~mm}$ long, outer bracts ovate, obtuse, the first one $8-10 \times 5-8 \mathrm{~mm}$, inner bracts lanceolate, obtuse, the first one $3-5 \times 1-2 \mathrm{~mm}$, flower-buds $6-8 \mathrm{~mm}$ long. Fourth calyx-lobe up to $8 \times 8 \mathrm{~mm}$, the spur patent, (slightly) incurved, up to $4 \mathrm{~mm}$ long. Petal white-yellowish, c. 10-13 $\times$ 8-10 mm, deeply two-lobed. Style pilose on the lower $2 / 3$ part. Fruit winged, the major wing oblong, 5-6 $\times 1 \frac{1}{2}-2 \mathrm{~cm}$, the second wing subelliptic, rounded, $2-3 \times 1-1 \frac{1}{2} \mathrm{~cm}$.

Holoty pe: Spruce 2889 in C, from Vaupés River (Brazil, Amazonas), duplicates in: BR, G, GOET, K, LD, NY, OXF, P, W; photograph of the C holotype in $\mathrm{GH}$ and $\mathrm{F}$.

Distribution: Upper Amazonia.

BRAZIL, Amazonas: Vaupés River, Spruce 2889; Rio Curicuriary, Ducke RB 34681; São Paulo de Olivença, Ducke RB 34680; Rio Solimões, Belém, Froes 23745.

Ecology: On terra firme in or along marshy places; f. Dec.-Febr., fr. Febr. (one report). "Perhaps the loftiest tree from which I have taken specimens" Spruce in mss.

3. Erisma costatum Stafl. nov. spec. (fig. 2).

Sectio Erisma. Ab E. floribundo Rudge petiolis longioribus, foliis subtiliter stellato-pilosis, nervis lateralibus paucioribus supra haud impressis, bracteis interioribus subulatis minimis differt.

\section{a. var. costatum}

Arbor. Ramuli juveniles, nervorum lateralium et costae pagina inferior, inflorescentia, calyx extra indumento denso fulvo instructi. Stipulae nullae. Gemmae ut in E. laurifolio pedicellatae. Folia opposita,

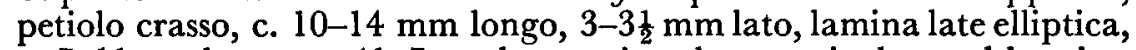
c. 7-11 cm longa, c. $4 \frac{1}{2}-7 \mathrm{~cm}$ lata, apice obtuse apiculata vel breviter acuminata, basi abrupte in petiolum attenuata, nervis supra haud impressis, lateralibus subtus fortiter prominentibus, utrinque 10-12, mediis sub angulo c. $40-60^{\prime}$ e costa ortis nervo limbali undulato margini proximo $(1-2 \mathrm{~mm})$ junctis. Paniculae cincinnis ad $2 \frac{1}{2} \mathrm{~cm}$ longis, bracteis exterioribus late ovatis, rotundatis, ad $9 \mathrm{~mm}$ longis, interioribus subulatis, 1-2 $\mathrm{mm}$ longis, alabastris $5-6 \mathrm{~mm}$ longis instructae. Calycis lacinia quarta calcare cylindrico, recurvo, c. 4-5 mm longo instructa. Petalum album basi flavum, ad $12 \times 12 \mathrm{~mm}$. Stamen glabrum. Staminodia c. $\frac{1}{2} \mathrm{~mm}$ longa. Stylus c. $6 \mathrm{~mm}$ longus, basi pilosus. 


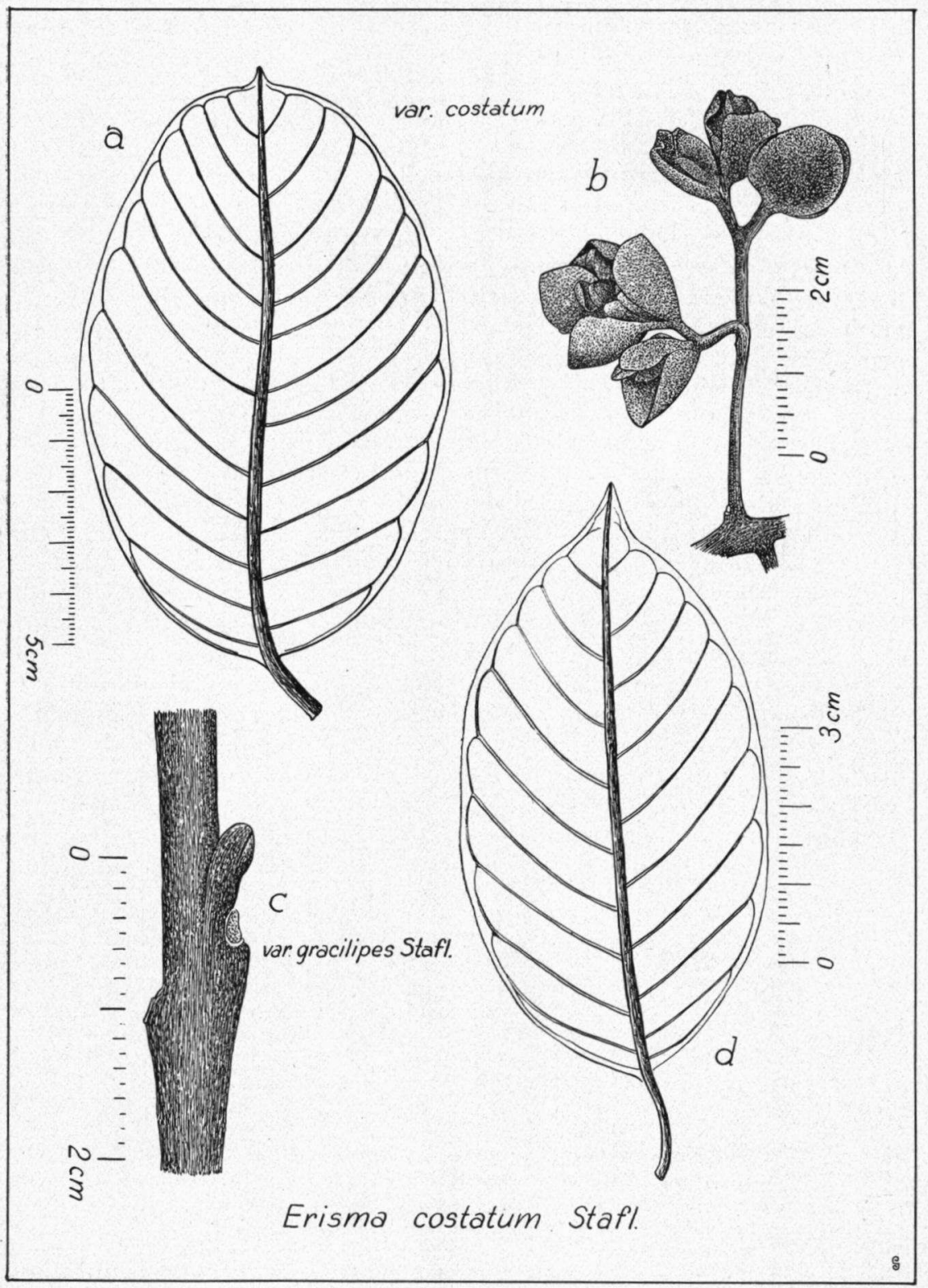

Fig. 2. Erisma costatum Stafl. $a$ \& b.: var. costatum, $a$. leaf, $b$. bracteate cincinni; c. \& d.: var. gracilipes Stafl., c. "pedicelled" bud, $d$. leaf

Holotypus: Ducke 1842 in $\mathrm{U}$ from Tabatinga (Goias, Brazil) in terra firme, fl. Nov., duplicates in F, GH, NY, RB, US, (= RB 60.347).

b. var. gracilipes Stafl. nov. var.

A var. costato petiolis gracilibus, c. $13-17 \mathrm{~mm}$ longis, c. $1 \frac{1}{2}-2 \mathrm{~mm}$ 
latis, laminis anguste ellipticis, c. $3 \frac{1}{2}-4 \frac{1}{2} \mathrm{~cm}$ latis, nervis lateralibus utrinque 9-11 instructis differt.

Holotypus: Fróes 23921 in U from Igarapé Jandiatuba (Brazil, Amazonas), defl. Jan., in terra firme, duplicate in IAN.

4. Erisma floribundum Rudge, Pl. Gui. Rar. 1: 7-8. t. 1. 1805 ("foribunda"); Trattinick 1811 p. 70; D.C. 1828 p. 30 ; A. Dietrich 1831 p. 101; D. Dietrich 1839 p. 21 ; Warming 1875 p. 108. t. 21 fig. 2. Debraea floribunda Roem. \& Schult. 1817 p. 34 . Ditmaria floribunda Spreng. 1825 p. $16,-1827$ p. 8. Erisma parvifolium Gleason 1933 p. 362 ; Ducke 1938 p. 43.

a. var. floribundum Erisma pallidiflorum Ducke 1935 p. 54 . Erisma barvifolium Gleason var. pallidiflorum Ducke 1938 p. 43.

Large tree. Young branchlets, leaves below, petioles, inflorescence, bracts and calyx densely brownish pilose. Stipules absent. Leaves opposite or in 3-4 merous whorls; petioles 4-9 mm long; leaf-blades obovate or elliptic, 9-16 $\times 3-6 \mathrm{~cm}$, the apex shortly acuminate, the base rounded or obtuse; lateral nerves strongly prominent below, impressed above, 12-17 major ones on each side, angle with the midrib $50-80^{\prime}$, arcuately anastomosing at $2-5 \mathrm{~mm}$ from the margin. Panicles provided with 2-5 flowered, $2-3 \mathrm{~cm}$ long cincinni, the peduncles 4-7 mm long, the pedicels $1-4 \mathrm{~mm}$ long, the outer bracts subovate, up to $10 \times 8 \mathrm{~mm}$, the inner bracts oblanceolate, "petioled", up to $5 \mathrm{~mm}$ long, the flower-buds $6-7 \mathrm{~mm}$ long. Fourth calyx-lobe up to $9 \times 9 \mathrm{~mm}$, the spur cylindrical, recurved, up to $5 \times 1 \mathrm{~mm}$. Petal pale yellow, glabrous, up to c. $15 \times 15 \mathrm{~mm}$. Staminodes 2-4, $\frac{1}{2}-1 \mathrm{~mm}$ long. Style glabrous, c. 5-6 $\mathrm{mm}$ long. Fruit winged, the major wing elliptic-oblong, c. $6 \times 2 \mathrm{~cm}$, obtuse; the second wing elliptic-oblong, c. $3 \times 1 \frac{1}{2} \mathrm{~cm}$, obtuse.

Holotype: Joseph Martin s.n. from French Guiana in BM, duplicates in BR and MO, fragments in M. (cf. remarks below). Debraea floribunda and Ditmaria floribunda are based on the same type (ncmenclatural synonyms). Holotype of E. parvifolium: Krukoff 1401 in NY, duplicates in: A, F, G, MO, P, S, U, US. Holotype of E. pallidiflorum and E. parvifolium var. pallidiflorum: Ducke RB 24102 in $R B$, duplicates in: $K, N Y, P, S, U$, US.

Distribution: Rare throughout the Amazonian basin. Type from French Guiana.

FRENCH GUIANA: Martin s.n.

VENEZUELA, Amazonas: Yavita, Ll. Williams 14111.

BRAZIL, A ma zonas: Manáos, Ducke RB 32144 ; Igarapé Mioá infra Camanáos, Rio Negro sup., Ducke RB 24102. Mat to Grosso: Upper Machado River region near Tabajara, Krukoff 1332, 1401; Jaturana River, Krukoff 1679.

Ecology: On terra firme, ff. Nov.-Dec., fr. Dec. (one report).

Remarks: The type specimen belonged to a set of plants collected by Joseph Martin in French Guiana and captured, on its way to France in the French warship l'Union, by two British privateers in 1803 or 1804. The plants came into the hands of Rudge who sent a set of 136 duplicate specimens to Martius (herbarium now in BR).

b. var. tomentosum (Ducke) Stafl. nov. comb. Erisma tomentosum Ducke 1935 p. 55. Erisma parvifolium Gleason var. tomentosum Ducke 1938 p. 43. 
Petal yellow with a white tip, the base unguiculate, densely lanuginose inside.

Holotype: Ducke RB 24100 in RB from Manáos (Brazil, Amazonas), duplicates in: $\mathrm{K}, \mathrm{NY}, \mathrm{P}, \mathrm{S}, \mathrm{U}$, US. The synonyms are based on the same type.

BRAZIL, Amazonas: Manáos, Ducke 104, RB 24100 and 24101.

Ecology: In terra firme forests, fl. Dec., fr. Apr. (one report).

5. Erisma bracteosum Ducke, Bull. Mus. Hist. Nat. Paris II. 4: 740. 1932; Ducke 1933 p. 48, - 1935 p. 56, - 1938 p. 42.

Large tree. Branchlets and leaves glabrous. Stipules triangular, c. $3 \mathrm{~mm}$ long, the apex subulate, deciduous, the base slightly incrassate. Leaves opposite; petioles firm, c. 8-15 mm long; leaf-blades elliptic or subovate-oblong, $12-22 \times 6-11 \mathrm{~cm}$, the apex shortly obtuseacuminate, the base rounded; major lateral nerves slightly prominent below, 7-11 on each side, angle with the midrib c. $60-70^{\prime}$, anastomosing at 3-7 $\mathrm{mm}$ from the margin, proper marginal nerve absent. Panicles when fresh white-yellowish, all parts densely fulvous pilose, the cincinni up to $4 \mathrm{~cm}$ long, up to 6 -flowered, the peduncles up to $7 \mathrm{~mm}$, the pedicels 1-2 $\mathrm{mm}$ long, the outer bracts suborbicular, diam. 8-11 mm, the inner bracts subulate, c. $1 \mathrm{~mm}$ long, the flowerbuds c. $10 \mathrm{~mm}$ long. Flowers fragrant. Fourth calyx-lobe up to $14 \times 14 \mathrm{~mm}$, the spur slightly recurved, subcylindrical. Petal yellow with a small red spot, up to $25 \times 25 \mathrm{~mm}$. Staminodes linear, $1-1 \frac{1}{2} \mathrm{~mm}$ long. Style $8 \mathrm{~mm}$ long, the lower half pilose. Fruit winged, the major wing oblong, rounded, up to $8 \times 2 \frac{1}{2} \mathrm{~cm}$, the second wing suboblong, rounded, up to $4 \times 1 \frac{1}{2} \mathrm{~cm}$.

Holotype: Ducke RB 23502 in RB from Borba (Brazil, Amazonas), duplicates in: $G, K, N Y, P, S, U$, US.

Distribution: Upper Amazonian basin.

BRAZIL, Amazonas: Borba, Rio Madeira inf., Ducke RB 23502; São Paulo de Olivença, Ducke RB 24037; São Jeronymo, Rio Solimões, Ducke RB 24038; Igarapé Belém, Rio Solimões, Fróes 23701; Camatian, Fróes 24014.

Ecology: On terra firme in humid forests, fl. Oct.-Jan., fr. Jan. (one report).

6. Erisma gracile Ducke, Arch. Inst. Biol. Veg. 2: 55. 1935; Ducke 1938 p. 44.

. Large tree. Young branchlets subpilose. Stipules subulate, caducous, 1-3 mm long. Leaves opposite, glabrous except for a few hairs on the blade below; petioles $6-8 \mathrm{~mm}$ long, slender; leaf-blades subcoriaceous, ovate-elliptic, $6-11 \times 2 \frac{1}{2}-4 \frac{1}{2} \mathrm{~cm}$, the apex obtuseacuminate, the base subacute, the lateral nerves very slightly prominent on both sides, 6-9 major ones on each side, angle with the midrib $60-80^{\prime}$, anastomosing at 3-6 $\mathrm{mm}$ from the margin, proper marginal nerve absent. Branchlets and peduncles of the panicles moderately, the other parts densely fulvous pilose, the cincinni $\frac{1}{2}-1 \frac{1}{2} \mathrm{~cm}$ long, 2-4 flowered, the peduncles $2-4 \mathrm{~mm}$ long, the pedicels $1 \frac{1}{2}-2 \frac{1}{2} \mathrm{~mm}$ long, the outer bracts subovate, up to $4 \times 4 \mathrm{~mm}$, the inner bracts linear-subulate, $\frac{1}{2}-1 \frac{1}{2} \mathrm{~mm}$ long, the flower-buds 4-5 $\mathrm{mm}$ long. Flowers when fresh white with a yellow petal. Fourth calyx-lobe c. $6 \times 6 \mathrm{~mm}$, the spur subglobose, pendent, diam. c. $1 \frac{1}{2} \mathrm{~mm}$. Petal c. $11 \times 9 \mathrm{~mm}$ the base pilose inside. Style 4-5 mm long, the base pilose. Fruit 
winged, the major wing oblong, up to $5 \times 1 \frac{1}{2} \mathrm{~cm}$, the second wing oblong, up to $2 \times 1 \mathrm{~cm}$.

Holotype: Ducke RB 24103 in RB from Rio Tarumá (Brazil, Amazonas), duplicates in: K, NY, P, S, U, US.

Distribution: Collected four times from the same tree.

BRAZIL, Amazonas: Rio Tarumá near Manáos, Ducke RB 24103, - 371.

Ecology: In rarely flooded riparian forest; fl. Dec.-Feb., fr. Apr. (one report).

7. Erisma tessmannii Pilger, Notizbl. Berlin 11:295. 1931.

Medium-sized tree. Young branchlets pilose. Leaves opposite; petioles c. $5 \mathrm{~mm}$ long, c. $1 \mathrm{~mm}$ wide, canaliculate above; leaf-blades glabrous or slightly pilose in youth, elliptic, $6-8 \frac{1}{2} \times 2-4 \mathrm{~cm}$, the apex shortly obtuse-acuminate, the base cuneate-rounded or rounded; the lateral nerves somewhat impressed above, slightly prominent below, $8-10$ on each side, angle with the midrib $60-80^{\prime}$, anastomosing near the margin, proper lateral nerve absent. Panicles loose, up to $12 \mathrm{~cm}$ long, all parts (probably) yellowish-brown pilose, the calyx tomentose outside, the cincinni 2-3 cm long, 3-6 flowered, the peduncles c. $5 \mathrm{~mm}$ long, the pedicels c. $1-3 \mathrm{~mm}$ long, the outer bracts subovate, rounded, up to $7 \mathrm{~mm}$ long, the inner bracts narrow-ovate, c. $3 \mathrm{~mm}$ long. Fourth calyx-lobe irregularly suborbicular, c. $9 \mathrm{~mm}$ long, the spur straight, subcylindrical, narrow, up to c. $4 \mathrm{~mm}$ long. Petal orange-coloured. Fruit winged, the major wing oblong, rounded, c. $5 \mathrm{~cm}$ long and c. $1 \mathrm{~cm}$ wide.

Holotype: Tessmann 4932 in B (now destroyed) from Peru, R. Marañon between Iquitos and Pongo de Manseriche, San Antonio, in forest on terra firme, $135 \mathrm{~m}$, fl. et fr. 14-1-1924 (photograph in F).

Remarks: No duplicate is known to the present author. Since no other material has come to hand, the above description has been based on Pilger's original description and the photograph of the holotype. The species seems to be well established, it differs from $E$. gracile by the larger flowers and the straight, narrow spur; it differs from $E$. floribundum e.g. by the small number of lateral nerves, the glabrous adult leaves, etc.

\section{section II Rixa Stafl.}

Sect. II Warming Fl. Bras. 13(2): 108. 1875.

Bracteae deciduae, parvae, exteriores flores insequentes ante evolutionem haud occultantes, interiores minimae vel nullae.

Holotypus: Erisma uncinatum Warm.

8. Erisma lanceolatum Stafl. nov. spec. (Fig. $3 a \& b$ ).

Erisma verisimiliter e sectione Rixa Stafl. petiolis nigris, gracilibus, laminis lanceolatis apice sensim acuto-acuminatis, fructibus ala majore elongato-elliptica instructis noscendum.

Arbor magna. Ramuli vetustiores cortice in squamulas parvas fisso instructi. Stipulae nullae. Folia opposita vel ternata, petiolo gracili, nigro, glabro, c. 12-15 mm longo; lamina subcoriacea, lanceolata, lanceolato-elliptica vel oblanceolata, $10-17 \mathrm{~cm}$ longa, $3 \frac{1}{2}-5 \frac{1}{2} \mathrm{~cm}$ lata, apice sensim acuto-acuminata, basi acuta vel obtusa, supra glabra nervis haud prominentibus, subtus parcissime pilosa; nervis lateralibus utrinque 6-8, curvatis, sub angulo c. $40-50^{\prime}$ e costa ortis, subtus 


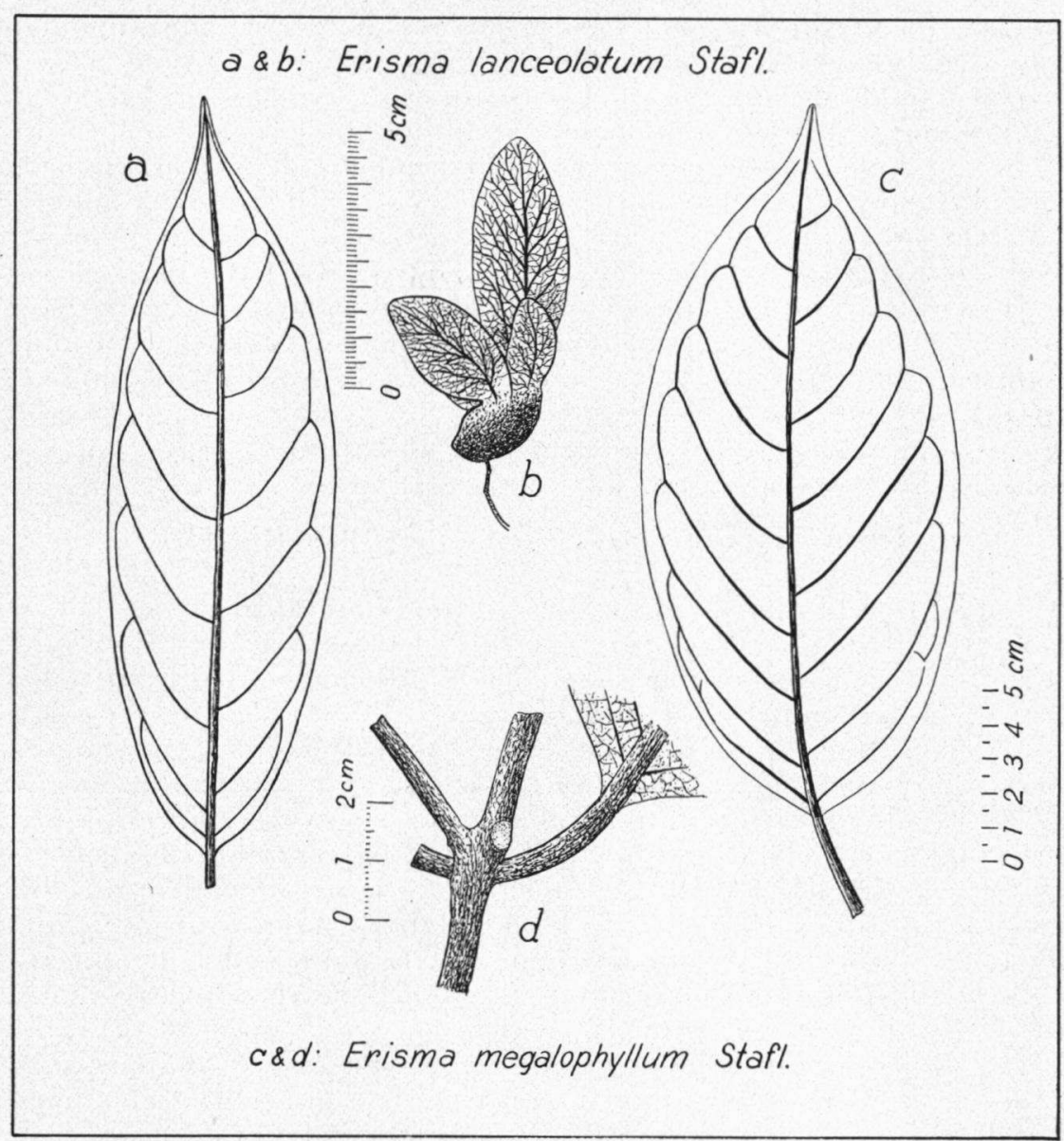

Fig. 3. a. $\mathcal{E}$ b.: Erisma lanceolatum Stafl., a. leaf, b. fruit; $c$. $\mathcal{E} d$. : Erisma megalophyllum Stafl., c. leaf, $d$. petiole

prominentibus, prope marginem arcuatim conjunctis, neque nervo limbali junctis. Paniculae amplae, ramulis gracilibus fusco-pilosis instructae. Fructus alati, parcissime stellato-pilosi, ala majore elongatoelliptica, subrotundata, ad c. $3 \mathrm{~cm}$ longa et $1 \frac{1}{2} \mathrm{~cm}$ lata instructi.

Holotypus: Fróes 12527/221 in A from Rio Castanha, affl. Rio Negro (Brazil, Amazonas), fl. 27-4-1942.

9. Erisma megalophyllum Stafl. nov. spec. (fig. $3 c \& d$ ).

Erisma verisimiliter e sectione Rixa Stafl. petiolis crassis, laminis fere glabris, magnis, apice acuto-acuminatis, nervis lateralibus utrinque 9 sub angulo c. $50^{\prime}$ e costa ortis instructis noscendum.

Arbor media. Ramuli subpilosi demum glabrati, cortice in squamulas parvas fisso instructi. Folia ternata (irregulariter, verticem unicum vidi); petiolo crasso, c. $2 \mathrm{~cm}$ longo; lamina elliptica, ad $23 \mathrm{~cm}$ 
longa et $11 \mathrm{~cm}$ lata, apice acuto-acuminata, basi subrotundata, supra glabra nervis haud prominentibus, subtus parcissime pilosa, nervis lateralibus utrinque $8-9$, curvatis, sub angulo c. $50^{\prime}$ e costa ortis, subtus fortiter prominentibus, prope marginem (6-9 $\mathrm{mm}$ ) arcuatim conjunctis, neque nervo limbali junctis. Paniculae amplae, ramulis modice, pedunculis, pedicellis, calyce dense fulvo-pilosis, cincinnis ad $2 \frac{1}{2} \mathrm{~cm}$ longis, 3- vel 4-floris, pedunculis c. 6-9 mm longis, pedicellis c. $1 \mathrm{~mm}$ longis, bracteis ignotis sed cicatricibus parvis (ergo species verisimiliter e sectione Rixa) instructae. Calycis laciniae prima, secunda et tertia suboblongae, obtusae, c. 3, 4-5 et 5-6 mm longae, quinta acuta, c. 4-5 mm longa, quarta decidua, ignota. Stylus c. $5 \mathrm{~mm}$ longus, basi pilosus.

Holotypus: Fróes 23741 in U, from Igarapé Belém, Rio Solimões (Brazil, Amazonas), in terra firme, defl. 18-12-1948, dupl. in IAN.

10. Erisma fuscum Ducke, Arch. Jard. Bot. Rio 4: 105. 1925; Ducke 1938 p. 44.

Large tree. Branchlets, petioles, stipules and leaf-blades below sparsely brownish pilose. Stipules sublanceolate, acute, 5-10 $\mathrm{mm}$ long, the apex caducous, the base persistent. Leaves opposite; petioles firm, c. $\frac{1}{2} \mathrm{~cm}$ long; leaf-blades obovate, $10-20 \times 7-12 \mathrm{~cm}$, the apex rounded, obtuse or apiculate, the base narrowly cordate; the lateral nerves prominent below, 9-12 on each side, angle with the midrib c. 50-60', disappearing near the margin or anastomosing, no proper marginal nerve. Panicles provided with sparsely pilose branchlets and peduncles, the other parts densely dark-brown tomentose, the cincinni up to $2 \mathrm{~cm}$ long, 3-5 flowered, the peduncles up to $5 \mathrm{~mm}$ long, the pedicels $\frac{1}{2}-1 \mathrm{~mm}$ long, the outer bracts caducous, linear, c. $\frac{1}{2}-1 \frac{1}{2} \mathrm{~mm}$ long, the flower-buds 5-6 mm long. Fourth calyx-lobe c. $6 \times 8 \mathrm{~mm}$, the spur strongly uncinate-incurved, up to $8 \times 4 \mathrm{~mm}$. Petal violaceous, up to $9 \times 9 \mathrm{~mm}$, whitish pilose on the inner side near the tip. Staminodes 3-4, lanceolate, c. $\frac{1}{2} \mathrm{~mm}$ long, sometimes in serial pairs. Style c. $6 \mathrm{~mm}$ long, pilose at the base. Fruit winged, the major wing elongate-elliptic, up to $7 \times 2 \frac{1}{2} \mathrm{~cm}$, the second wing elliptic, up to $1 \frac{1}{2} \mathrm{~cm}$.long, the calyx-cup longitudinally ribbed.

Holotype: Ducke RB 17745 in RB from Antonio Lemos near the River Tajapurú (Brazil, Para) in terra firme forest, fl. Dec. fr. March, duplicates in $\mathrm{G}, \mathrm{K}, \mathrm{P}, \mathrm{S}, \mathrm{U}$, US.

11. Erisma micranthum Spruce ex Warm. Fl. Bras. 13(2): 112.1875.

Small tree. Branchlets and leaves glabrous. Stipules c. $1 \mathrm{~mm}$ long, the apex deciduous, the base incrassate and persistent. Leaves opposite; petioles 3-5 $\mathrm{mm}$ long; leaf-blades pergamentaceous, elongate-ovate or -subelliptic, c. 9-16 $\times 3 \frac{1}{2}-6 \mathrm{~cm}$, the apex gradually acuminate or obtuse, the base more or less rounded; the lateral nerves slightly prominent, $7-11$ on each side, angle with the midrib $60-80^{\prime}$, curved upwards and anastomosing near the margin, no proper marginal nerve. Branchlets of the panicles and peduncles sparsely, the pedicels and the calyx densely greyish pilose; the cincinni up to $1 \frac{1}{2} \mathrm{~cm}$ long, 
2-5 flowered, the peduncles $2-4 \mathrm{~mm}$ long, the pedicels $\frac{1}{2}-1 \mathrm{~mm}$ long, the bracts caducous, the flower-buds up to $4 \mathrm{~mm}$ long. Fourth calyx-lobe 3-4 $\times 4-4 \frac{1}{2} \mathrm{~mm}$, the spur subcylindrical, straight, c. $1 \frac{1}{2} \mathrm{~mm}$ long. Petal yellow with a red base, pilose inside. Style c. $2-3 \mathrm{~mm}$ long, glabrous. Fruit winged, the major wing up to $10 \mathrm{~mm}$ long, the second wing up to $7 \mathrm{~mm}$ long, the calyx-cup longitudinally ribbed.

Holotype: Spruce 3767 in C from San Carlos, Rio Negro (Venezuela), duplicates in. BR, G, GH, GOET, K, OXF, $P, W$ ).

Distribution: Upper Amazonia.

VENEZUELA, Amazonas: San Carlos, Rio Negro, Spruce 3767.

BRAZIL, Amazonas: Rio Iá, Rio Negro, Fróes 22392; Içana, Rio Negro, Fróes 22276; Rio Curicuriary, Rio Negro, Ducke RB 34.684.

Ecology: On terra firme, in high forest along river banks; fl. Nov., Dec., June (3 reports), fr. May (1 report).

12. Erisma nitidum D.G. Prodr. 3: 30. 1828; Warming 1875 p. 112; Benoist 1915 p. $237,-1931$ p. 167 ; Stafleu 1951 p. 199; Lemée j1952 p. 243. Qualea lutea Martin 'ex D.G. 1828 p. 30 in synon.

Large tree. Branchlets and leaves glabrous. Stipules c. 2-3 mm long, the apex subulate, caducous, the base partly persistent. Leaves opposite; petioles 8-10 $\mathrm{mm}$ long; leaf-blades thinly coriaceous, shining above, elliptic, $11-15 \times 5-7 \mathrm{~cm}$, the apex shortly obtuseacuminate, the base subobtuse, the major lateral nerves 7-9 on each side, subprominent below, angle with the midrib c. $60-70^{\prime}$, the marginal nerve undulate, at 5-7 $\mathrm{mm}$ from the margin. Branchlets and peduncles of the inflorescence sparsely, pedicels and calyx densely fulvous pilose, the cincinni up to $3 \mathrm{~cm}$ long, 3-6 flowered, the peduncles up to $7 \mathrm{~mm}$ long, the pedicels c. $1 \mathrm{~mm}$ long, the outer bracts ovate, 2-3 mm long, the flower-buds 5-6 mm long. Fourth calyx-lobe 6-7 $\times$ 7-8 $\mathrm{mm}$, the spur straight, subconical, $4-5 \mathrm{~mm}$ long, obtuse. Petal white with a yellow centre. Staminodes often in serial pairs, c. $\frac{1}{2} \mathrm{~mm}$ long. Style c. $6 \mathrm{~mm}$ long, lower half pilose. Fruit winged, the major wing subelliptic, c. $5 \times 2 \mathrm{~cm}$, the second wing subelliptic, c. $3 \frac{1}{2} \times 1 \frac{1}{2} \mathrm{~cm}$, the calyx-cup longitudinally ribbed.

Holotype: Joseph Martin s.n. in FI, from Roura Mt., French Guiana, duplicate in P. This specimen is also the holotype of Qualea lutea Martin ex D.C. in synon.

Distribution: French and British Guiana.

FRENCH GUIANA: Mt. Roura, Martin s.n.; Leprieur 289.

BRITISH GUIANA: Potaro River, Cobanatuk Falls, Jenman 7439; Potaro River, Mahdia, For. Dept. Br. Gui. 3743.

Ecology: In British Guiana in "Wallaba forest on white sand"; fl. Oct., Nov., fr. Nov. (one report).

Remarks: The specimens cited by Ducke (1933 p. 48; 1938 p. 43) as Erisma nitidum belong to 16 Erisma splendens q.v.

13. Erisma japura Spruce ex Warm. Fl. Bras. 13(2): 109. t. 21 fig. 1, 1875; Petersen 1896 fig. 173 G; Ducke 1938 p. 44.

Large tree. Branchlets, petioles, leaves below and inflorescence slightly, pedicels and calyx densely greyish pilose. Stipules small, subulate, deciduous. Leaves in tri- or tetramerous whorls; petioles $2 \frac{1}{2}-4 \mathrm{~cm}$ long; leaf-blades rigidly coriaceous, elliptic or obovateelliptic, $10-23 \times 4-10 \mathrm{~cm}$, the apex rounded or nearly truncate, 
emarginate, the base acute, the lateral nerves prominent below, $15-18$ on each side, angle with the midrib $60-70^{\prime}$; the marginal nerve undulate, at $1-3 \mathrm{~mm}$ from the margin. Cincinni up to $5 \mathrm{~cm}$ long, 5-7 flowered, the peduncles 5-20 mm long, the pedicels 3-6 mm long, the outer bracts up to $10 \times 5 \mathrm{~mm}$, elliptic-ovate, the inner bracts absent, the flower-buds c. $12 \mathrm{~mm}$ long. Fourth calyx-lobe up to $14 \times 18 \mathrm{~mm}$, the spur bag-shaped, rounded, c. $3 \times 3 \mathrm{~mm}$. Petal yellow, c. $2-2 \frac{1}{2} \times 2 \frac{1}{2}-3 \frac{1}{2} \mathrm{~cm}$. Staminodes lanceolate, c. $3 \frac{1}{2} \times 1 \mathrm{~mm}$. Style c. 10-12 mm long. Fruit winged, the major wing up to $13 \times 4 \mathrm{~cm}$, the second wing up to $7 \times 2 \frac{1}{2} \mathrm{~cm}$, both oblong and provided with 6-8 parallel nerves; limb ellipsoid, smooth, up to $4 \frac{1}{2} \times 2 \frac{1}{2} \mathrm{~cm}$, seeds oblong, c. $3 \times 1 \mathrm{~cm}$.

Holotype: Spruce 2613 in C from Rio Vaupés (Brazil, Amazonas), see remarks below. Duplicates in: BR, F, G, GH, GOET, K, NY, OXF, P, S, W.

Distribution: Northern Upper Amazonia.

BRAZIL, A mazonas: Near Panuré on Rio Vaupés, Spruce 2613; São Gabriel, Rio Negro, Ducke RB 23798; Içana, Rio Negro, Fróes 22290; Marabitanas, Rio Negro, Murça-Pires 470; Rio Curicuriary, Rio Negro, Ducke RB 34678.

Ecology: On terra firme; fl. Oct., Nov. April (3 reports), fr. Febr., May (2 reports).

Vernacular names: Japura (Brazil, Rio Negro).

Remarks: The flowers of Spruce 2613 were collected in Nov. 1852, the fruits in Febr. 1853. These collections were made (apparently) from different trees. The flowers and fruits certainly belong to the same species.

Spruce, in a mss note on the Kew specimen, says that "the kernels are pleasant eating, both raw and boiled"... "The Japurá-butter is eaten along with fish and game .... People who can get over its vile smell (which is never lost) find it exceedingly savoury".

14. Erisma calcaratum (Link) Warm. Fl. Bras. 13(2): 111. 1875; Warming 1889 p. 28; Glaziou 1905 p. 31 ; Ducke 1915 p. 50, - 1922 p. 198, - 1925 p. 107 pl. $13 a$ \& b, - 1938 p. 44; Lecointe 1934 p. 212; Macbride 1950 p. 873 . Qualea calcarata Link 1820 p. 24; Roem. \& Schult. 1822 p. 53. Erisma violaceum Mart. 1824 p. 137 t. 82; D.C. 1828 p. 30; A. Dietrich 1831 p. 102; D. Dietrich 1839 p. 21; Schomburgk 1848 p. 1099; Baillon 1874 p. 96 fig. 135, 136. Debraea violacea Steud. 1841 p. 486. Ditmaria violacea Spreng. 1827 p. 8.

Small or medium-sized tree. Branchlets and leaves glabrous. Stipules persistent, triangular, 3-5 $\mathrm{mm}$ long, the apex subulate, the bases widened, connate and constituting a ridge. Leaves opposite; petioles $3-6 \mathrm{~mm}$ long; leaf-blades generally elliptic or ovate-elliptic, $16-24 \times 6-8 \frac{1}{2} \mathrm{~cm}$, the apex acuminate, the base rounded or cordate; the lateral nerves subprominent below, 7-10(-12) on each side, angle with the midrib $60-80^{\prime}$, curved upwards, anastomosing or ending in the margin, no proper marginal nerve. Branchlets and peduncles of the inflorescence slightly, pedicels and calyx densely greyish pilose; the cincinni 3-5 mm long, 3-5 flowered, the peduncles up to $10 \mathrm{~mm}$ long; the pedicels $1-2 \mathrm{~mm}$ long, the outer bracts ovate, falling early, the inner bracts subulate, caducous, the flower-buds up to $10 \mathrm{~mm}$ long. Fourth calyx-lobe violaceous, c. $10 \times 13 \mathrm{~mm}$, the spur conical, 3-6 mm long, slightly incurved, stretched along the pedicel. Petal blue or violaceous, c. $18 \times 18 \mathrm{~mm}$. Staminodes 
linear, c. $\frac{1}{2} \mathrm{~mm}$ long. Style glabrous, up to $9 \mathrm{~mm}$ long. Fruits not winged, 4-6 6 2-3 mm, 士 oblong, slightly curved, consisting of the enlarged woody calyx-cup which almost completely encloses the true fruit, cup longitudinally ribbed and provided with numerous warts; the calyx-lobes persistent but not enlarged.

Holotype: Hoffmannsegg s.n. from Para (Brazil) in herbarium Willdenow in B (preserved) (the true collector is probably $F . W$. Sieber, Hoffmannsegg's servant). Since Erisma violaceum is an avowed synonym of Qualea calcarata, its holotype is also this same specimen. Debraea violacea and Ditmaria violacea are in their turn avowed synonyms of Erisma violaceum.

Distribution: Amazonian basin.

BRAZIL, Pa ra: Hoffmannsegg (Sieber) s.n.; G. A. Black 48-2951; Ducke PG 10144, PG 16536, RB 17765; Fróes 20296; Guedes PG 584, PG 1665, PG 2229; Kuhlmann RB 17771; Martius s.n.; Mexia 6056; Schwacke III 556; Sigueira PG 3772; Spruce 125. Amazon as: Manáos, Spruce 1798; -, Ducke 897; Upper Rio Negro, Ro. Schomburgk 868, 898; Padauiry, Rio Negro, Fróes 22677; Lower Rio Negro, Ducke 756; Foz do Jatahy, Ducke RB 20561.

PERU, Loreto: Iquitos, Tessmann 5330; Mishuyaca, Klug 1541.

Ecology: Typical varzea tree, fruits adapted to water transport; fl. May-Oct. from the middle of the dry season to the beginning of the "winter" fr. Nov.-Apr.

Vernacular names: Para: Jaboty-araconha, Jaboty, Jaboty da Varzea, Cachimbo de jaboti, Caramurú, Aburána, Vergalho de jaboti.

Use: The fruit yields an industrial oil "jaboty" used e.g. for the manufacture of soap. The wood seems to be useless as timber but can be used for the manufacture of paper.

Remarks (1) The species is mentioned from French Guiana by Lemé (1952) but this is apparently erroneous since no specimen of this species collected by Sagot (as indicated by Lemée) is preserved in the Paris herbarium.

(2) The fruit has the shape of a pipe and its name "Cachimbo de jaboty" is derived from this characteristic: pipe of the jaboty, a kind of terrestrial tortoise (Ducke).

(3) All species of Erisma, except the present one, are found in terra firme forests. All terra firme species have winged "dipterocarpaceous" fruits; the present species, inhabiting the regularly inundated varzea woods, has wingless fruits specially adapted to water-transport. The figure of the fruit in Baillon (1.c. fig. 137) does not represent the fruit of $E$. calcaratum.

15. Erisma uncinatum Warm. Fl. Bras. 13(2): 110. 1875; Wille 1882 p. 181 (anat.); Warming 1889 p. 28; Pulle 1906 p. 134; Ducke 1915 p. $51,-1922$ p. $198,-1925$ p. $106,-1938$ p. 44 ; Benoist 1915 p. $237,-1919$ p. 319 , - 1931 p. 167 , 168; Pfeiffer 1926 p. 357; Lecointe 1934 p. 211 ; Amshoff 1948 p. 11; Mennega 1948 p. 47 (anat.); Macbride 1950 p. 875; Stafleu 1951 p. 197; Lemée 1952 p. 243. Erisma pulverulentum Poeppig ex Warm. 1889 p. 28 (in synon.).

Large tree. Branchlets, petioles and leaves below slightly, inflorescence densely greyish (the calyx often violaceous) pilose. Stipules subulate, 1-2 mm long, the base incrassate. Leaves opposite or in tri- or tetramerous whorls; petioles $1-2 \mathrm{~cm}$ long; leaf-blades elongateobovate or -oblong, $10-17 \times 4 \frac{1}{2}-8 \mathrm{~cm}$, the apex rounded, obtuse or apiculate, the base cuneate, the lateral nerves $4-7(-10)$ on each side, angle with the midrib $40-70^{\prime}$, curved upwards near the margin,

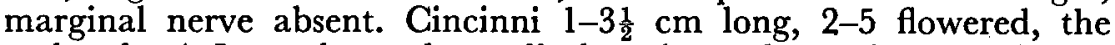
peduncles 4-5 $\mathrm{mm}$ long, the pedicels $\mathrm{c}$. $1 \mathrm{~mm}$ long, the outer bracts ovate, rounded or obtuse, 3-5 $\mathrm{mm}$ long, the inner bracts linear, 
acute, 1-2 mm long, the flower-buds 5-7 mm long. Fourth calyx-lobe c. 5-7 $\times 8-10 \mathrm{~mm}$, the spur strongly uncinate-incurved, compressed, often larger than the bud, $2-2 \frac{1}{2} \mathrm{~mm}$ wide, apically rounded. Petal violaceous, $12-15 \times 12-15 \mathrm{~mm}$. Staminodes $0-4$, filiform, $\frac{1}{2}-1 \frac{1}{2} \mathrm{~mm}$ long, sometimes forked or in serial pairs. Style up to $7 \mathrm{~mm}$ long, the lower half pilose. Fruit winged, the major wings elliptic-oblong, $4-7 \times 1 \frac{1}{2}-3$ and $2 \frac{1}{2}-3 \times 1-1 \frac{1}{2} \mathrm{~cm}$ respectively.

Typification: Warming mentions specimens collected by Poeppig and Riedel. Poeppig 2633 in W from Ega, Brazil, is here proposed as the lectotype. (Duplicates: BM, F, G, GOET, L, US).

Distribution: Amazonian basin and Guiana.

BRAZIL, Para: Ducke PG 15878, PG 16390, RB 13691; Goeldi PG 8322; Gueces PG 2136; Sigueira PG 8827; N.T. Silva 136. A mazonas: Ducke RB 20560, RB 23797, 264 (= RB 34679); Fróes 23694; Krukoff 5603, 8084; Poeppig 2633; Riedel s.n.; Spruce s.n. Maranhao: Marucassumé River, Fróes. 1939; AssulinaCarutapera, Fróes 11953.

SURINAME: B.W. (= Boschwezen) nos: 491, 1350, 1402, 1428, 2475, 3342, 3380, 3544 3580, 4751, 5434, 5564; Boschbeheer 46; Woodherbarium 46. (Full details in Stafleu 1951 p. 198).

FRENCH GUIANA: Benoist 366, 1233, 1535; Mélinon s.n. div. coll.; Gandoger 8; Wachenheim 407.

BRITISH GUIANA: Kanuku Mts, For. Dept. Br. G. 5801, 5929.

Ecology: In primary forests on terra firme; fl. July-Nov., fr. Sept., Jan. ( 2 reports).

Vernacular names: BRAZIL, Para: Quaruba, Quaruba de flores roxas (Lecointe), Jaboty da terra firme. Maranhao: Bruto. BRITISH GUIANA: Pramaye. SURINAME: e.g, Singri-kwarrie (vide Stafleu 1951 p. 198).

16. Erisma splendens Stafl. nov. spec. (fig. 4).

Sectio Rixa Stafl. Ab E. uncinato Warm. foliis glabris, nervis lateralibus pluribus haud prominentibus, floribus indumento sordide flavescento, calcari subconico parum incurvo instructis, petalo intus albo-lanuginoso differt.

Arbor magna. Ramuli subpilosi demum glabrescentes, decorticantes. Stipulae $2-3 \mathrm{~mm}$ longae, basi incrassatae, apice subulato deciduo instructae. Folia glabra, opposita; petiolo 15-20 mm longo; lamina

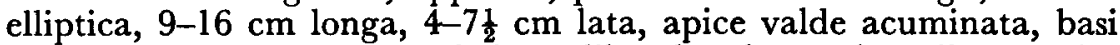
cuneata, supra nitida; nervis lateralibus haud prominentibus, majoribus utrinque 9-15, sub angulo c. 60-70' e costa ortis, nervo limbali undulato margini proximo junctis. Ramuli paniculae, pedunculi parce pilosi, bracteae, pedicelli, calyx dense sordide flavescenti-pilosi. Cincinni ad $15 \mathrm{~mm}$ longi, 3-5 flori, bracteis exterioribus subellipticis, c. $2 \mathrm{~mm}$ longis, interioribus lineari-subulatis, c. $\frac{1}{2}-1 \mathrm{~mm}$ longis, pedunculis ad $5 \mathrm{~mm}$, pedicellis ad $2 \mathrm{~mm}$, alabastris c. $4 \mathrm{~mm}$ longis instructi. Calycis lacinia quarta c. $6 \mathrm{~mm}$ longa et $7 \mathrm{~mm}$ lata, calcari dependente, subconico, c. $2-2 \frac{1}{2} \mathrm{~mm}$ longo et $1 \frac{1}{2}-2 \mathrm{~mm}$ lato parum incurvo instructa. Petalum extra album vel pallide lilacinum, intus flavum, dense albo-lanuginosum, c. 10-12 $\mathrm{mm}$ longum et latum. Petalum rudimentarium nonnunquam adest, spathulatum, dense lanuginosum, inter sep. 4 et 2 positum. Staminodia c. $\frac{1}{2}-1 \mathrm{~mm}$ longa. Stylus basi pilosus. Ala major fructuum elongato-elliptica, ad c. $7 \mathrm{~cm}$ longa et $2 \frac{1}{2} \mathrm{~cm}$ lata, ala secunda oblonga, ad c. $3 \frac{1}{2} \mathrm{~cm}$ longa et c. $18 \mathrm{~mm}$ lata. 


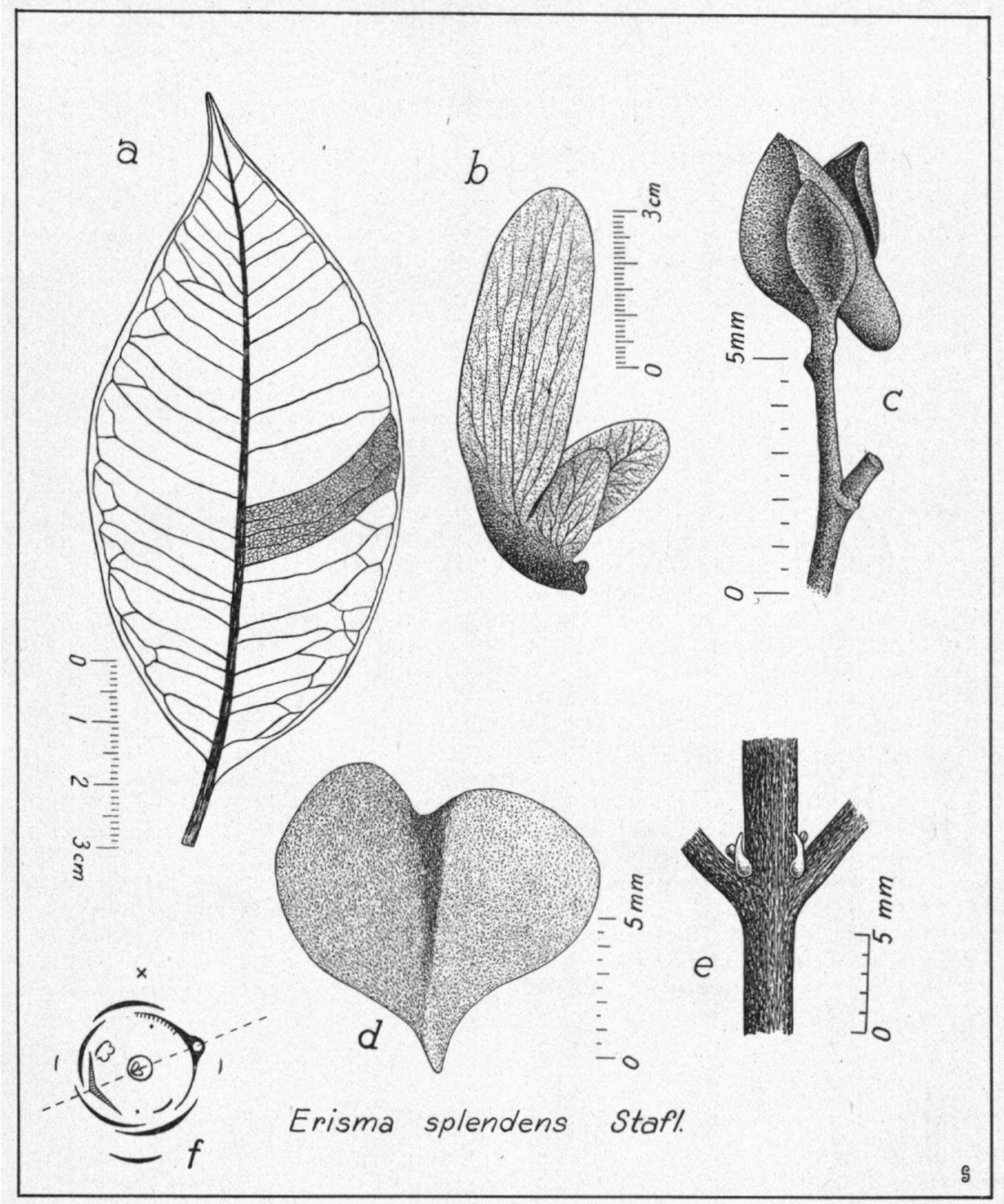

Fig. 4. Erisma splendens Staf. a. leaf, $b$. fruit, c. flower-bud, d. petal, e. stipules, $f$. diagram

Holotypus: Ducke RB 34682 in U from Manáos (Brazil, Amazones), duplicates in: $G, K, P, S$, U, US.

Distribution: Central Amazonia.

BRAZIL, Amazonas: Manáos, Ducke RB 34682, RB 23501, RB 34683, 96.

Ecology: In marshy forests on terra firme; fl. Nov.-Dec., fr. Feb.

Species dubiae

17. Erisma maliforme Link ex A. Dietrich, Sp. Pl. ed. 6. 102. 1831 ("maliformis"); Warming 1875 p. 114. 
The description of this species does not enable us to run it down to one of the known species of Erisma. It is so incomplete that it is even uncertain whether Link's specimen was indeed an Erisma. The specimen was preserved in Link's herbarium and was destroyed with the other Berlin collections.

18. Erisma niveum Link ex A. Dietrich, Sp. Pl. ed. 6. 102. 1831 ("nivea"); Warming 1875 p. 114.

It is not possible to identify this species: the description is too incomplete and Link's original specimen was destroyed together with the Berlin collections.

\section{Collectors' numbers}

The numbers in parentheses refer to the serial numbers of the species of Erisma. The letter $a$ refers to the subdivision containing the nomenclatural type of the species, the letter $b$ to the second subdivision of that species.

Benotst 366 (15), 1233 (15), 1535 (15). BLACK, G. A. 48-2951 (14). BoschbeheER 46 (15). B.W. 491, 1350, 1402, 1428, 2475, 3342, 3380, 3544, 3580, 4751, 5434, 5564 (all 15). DuCKe 96 (16), $104(4 b), 264$ (15), 371 (6), 756 (14), 897 (14), 1842 (3a), PG 10144 (14), PG 15878 (15), PG 16390 (15), PG 16536 (14), RB 13691 (15), RB 17745 (10), RB 17765 (14), RB 20560 (15), RB 20561 (14), RB 23500 (1a), RB 23501 (16), RB 23502 (5), RB 23796 (1a), RB 23797 (15), RB 23798 (13), RB 24037 (5), RB 24038 (5), RB 24100 (4b), RB 24101 (4b), RB 24102 (4a), RB 24103 (6), RB 32144 (4a), RB 34678 (13), RB 34679 (15), RB 34680 (2), RB 34681 (2), RB 34682 (16), RB 34683 (16), RB 34684 (11), RB 34685 (1b), RB 60347 (3a). Forest Dept. BR. Gur. 3743 (12), 5801 (15), 5929 (15). Frófs 1939 (15), 11953 (15), 12527/221 (8), 20296 (14), 22276 (11), 22290 (13), 22392 (11), 22677 (14), 23694 (15), 23701 (5), 23741 (9), 23745(2), $23921(3 b), 24014$ (5). Gandoger 8 (15). Goeldi PG 8322 (15). Guedes PG 584 (14), PG 1665 (14), PG 2136 (15), PG 2229 (14). Jenman 7439 (12). Klug 1541 (14). KRUKOFF 1332 (4a), 1334 (1a), 1376 (1a), 1401 (4a), 1679 (4a), 5603 (15), 8084 (15), 8892 (1b). Kuhlmann RB 17771 (14). Leprieur 289 (12). Mexia 6056 (14). Murça Pires 470 (13). Poeppig 2633 (15). Schomburgk 868 or 898 (14). Schwacke III 556 (14). Sigueira PG 3772 (14), PG 8827 (15). Silva, N.T. 136 (15). Spruce 125 (14), 1798 (14), 2613 (13), 2889 (2), 3767 (11). Tessmann 4932 $(7), 5330$ (14). Wachenheim 407 (15). Williams, LL. 14111 (4a). WoOdherbarium $46(15)$.

\section{Vernacular names}

The numbers refer to the serial numbers of the species of Erisma.

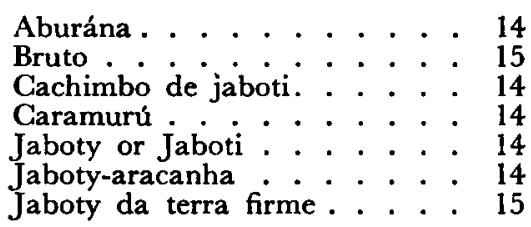

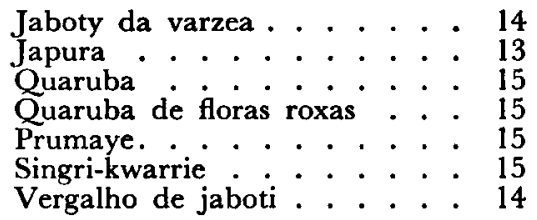

\section{Specific and infraspecific names}

The numbers refer to the serial numbers of Erisma under which the names are cited. Names printed in italics are synonyms; those printed in bold face type refer to new taxa.

\section{Debraea}

floribunda Roem \& Schult. . . 4 violacea Steud. ..... 14

\section{Ditmaria}

floribunda Spreng. . . . . . . 4 


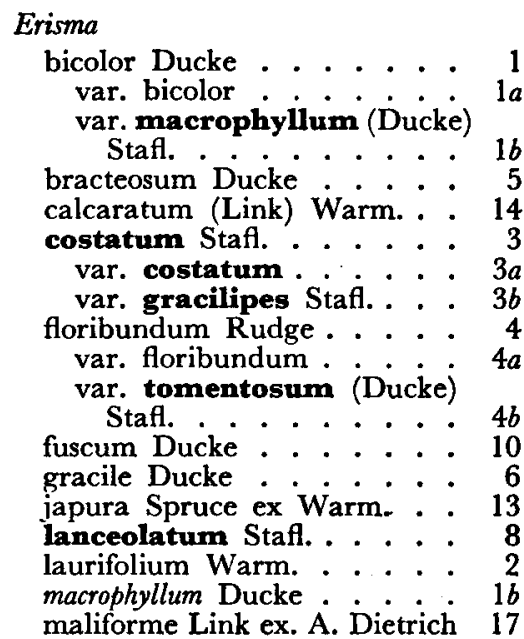

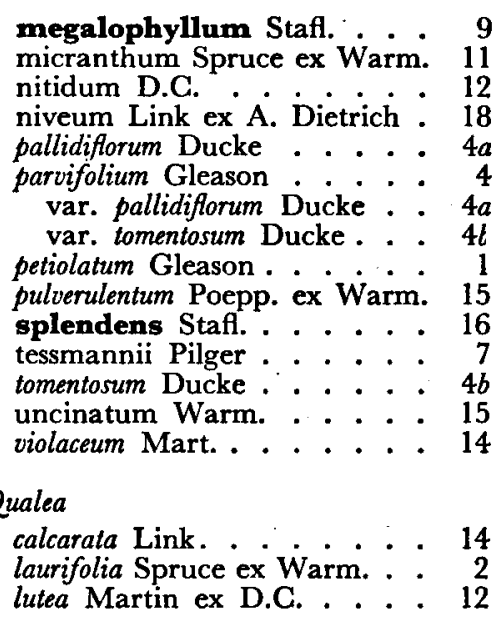

\section{REFERENCES}

Aмsнof;, G. J. H. 1948. Enumeration of the herbarium specimens of a Suriname wood collection made by Prof. G. Stahel.

Balllon, J. B. C. F. 1874. Histoire des Plantes 5.

Bentham, G. \& J. D. Hooker 1862-67. Genera Plantarum 1.

Benorst, R. 1915. Bull. Soc. Bot. France 62.

Benoist, R. 1919. Bull. Soc. Bot. France 66.

Benoist, R. 1931. Arch. Botanique 5. mém. 1.

CANDolle, A. P. DE 1828. Prodromus systematis naturalis regni vegetabilis 3 .

Chevalier, A. \& Russel 1929. Compt. Rend. Acad. Sci. 188.

Dietrich, A. 1831. Caroli a Linné Species Plantarum ed. 6. 1.

Dietrich, D. 1839. Synopsis Plantarum 1.

Dugke, A. 1915. Arch. Jard. Bot. Rio 1.

Ducke, A. 1922. Arch. Jard. Bot. Rio 3.

Ducke, A. 1925. Arch. Jard. Bot. Rio 4.

Ducke, A. 1932. Bull. Mus. Hist. Nat. Paris II. 4.

Ducke, A. 1933. Arch. Jard. Bot. Rio 6.

Ducke, A. 1935. Arch. Inst. Biol. Veg. 2.

DuCKe, A. 1938. Arch. Inst. Biol. Veg. 4.

Dumortier, B. C. 1829. Analyse des Familles des Plantes.

ENDlicher, S. 1836-40. Genera Plantarum.

Graziou, A. F. M. 1905. Bull. Soc. Bot. France 52. mém. 3.

GleAson, H. A. 1933. Bull. Torrey Bot. Cl. 60.

Keay, R. W. J. \& F. A. Stafleu 1952. Acta Bot. Neerl. 1 (4); also in Med. Bot. Mus. Utrecht 114.

Lanjouw, J. \& F. A. Stafleu 1954. Index Herbariorum, part. I: The Herbaria of the World, second ed., Regnum Vegetabile 2 (1).

Lecointe, P. 1934. A Amazonia Brasileira 3.

LEMÉ, A. 1952. Flore de la Guyane Française 2.

Lisk, H. 1822. Jahrb. Gewächskunde 1 (3).

MAcBride, J. F. 1950. Fieldiana Botany 13 (3).

Martius, C. F. P. von \& J. G. Zuccharini 1824. Nova Genera et Species Plantarum 1.

Meisner, K. F. 1836-43. Plantarum vascularium genera 1.

Mennega, A. M. W. 1948. Suriname Timbers 1.

MeYer, E. 1825. Nov. Act. Leop. 12.

Petersen, O. G. 1896. Vochysiaceae in Engler \& Prantl, Nat. Pf. fam. 3 (4).

Pilger, R. 1931. Notizbl. Berlin 11. 
Pfeiffer, J. Ph. 1926. De Houtsoorten van Suriname I. Med. Kol. Inst. 1926. Poeprig, E. F. 1833. Frorieps Notizen 35 (8).

Pulle, A. A. 1906. An enumeration of the vascular plants known from Surinam. Roemer, J. J. \& J. A. Sahultes. 1817. Caroli a Linné Systema Vegetabilium 1. Roemer, J. J. \& J. A. Schultes 1822. Mantissa 1.

RUDGE, E. 1805. Plantae Guianenses 1.

Schomburgk, R. I. 1848. Reisen in British Guiana 3.

SPRENGeL, G. (K.) 1818. Anleitung etc. 2 (2).

SPRENGEL, C. (K.) 1825. Syst. Veg. ed. 16. 1.

Sprengel, C. (K.) 1827. Idem 4, Cur. Post.

Stafleu, F. A. 1948. A Monograph I, Rec. Trav. Bot. Néerl. 41; also in Med. Bot. Mus. Utrecht 95.

Stafleu, F. A. 1951. Vochysiaceae in Pulle, Flora of Suriname 3 (2).

Stafleu, F. A. 1952. A Monograph II, Acta Bot. Néerl. 1, also in Med. Bot. Mus. Utrecht 108.

Staflev, F. A. 1953. A Monograph III, Acta Bot. Neerl. 2, also in Med. Bot. Mus. Utrecht 116.

Stafleu, F. A. cf. Keay, R. W. J. \& F. A. Stafleu, 1952 and Lanjouw, J. \& F. A. Stafleu 1954.

Steudel, E. G. 1841. Nomenclator Botanicus, ed. 1.

Trattinick, L. 1811. Observationes botanicae 3 .

Warming, E. 1875. Flora Brasiliensis 13 (2).

Warming, E. 1889 . Vid. Med. Nat. För. 1889.

Wille, N. 1882. Overs. Kgl. Dansk. Vid. Selsk. För. 1882. 